\title{
Develop Sustainable Livelihoods for Fishermen in the North Central Region of Vietnam - Case Study for Nghe An Province
}

\author{
Yen Hoang Phan Hai \\ School of Social Sciences Education, Vinh University, Vietnam \\ Email: hoangphanhaiyen@vinhuni.edu.vn \\ Vinh Luong Thi Thanh (Corresponding Author) \\ School of Social Sciences Education, Vinh University, Vietnam \\ Email:vinhltt@vinhuni.edu.vn
}

\begin{abstract}
Tuyen Tran Thi (Corresponding Author)
Department of Resource and Environment Management, Vinh University, Vietnam

Email: tuyentt@vinhuni.edu.vn
\end{abstract}

Hoai Nguyen Thi

School of Social Sciences Education, Vinh University, Vietnam

Email: hoaint@vinhuni.edu.vn

Thanh Nguyen Thi Trang

School of Social Sciences Education, Vinh University, Vietnam

Email: thanhntt@vinhuni.edu.vn

Tran Tuan Nguyen

School of Agriculture and Natural Resources, Vinh University, Vietnam

Department of Economic and Social Geography, University of Szeged, Hungary

Email: nttuan@vinhuni.edu.vn 
Received: Oct. 9, 2019

doi:10.5296/jas.v8i1.15413
Accepted: Oct. 24, 2019

Published: Nov. 11, 2019

URL: https://doi.org/10.5296/jas.v8i1.15413

\begin{abstract}
Livelihoods and sustainable livelihoods play a very essential role in coastal fishing communities in Vietnam. In this paper, based on the sustainable livelihood model, we evaluate the current situation of coastal fishing livelihoods in the North central region of Vietnam with case study for Nghe An province and identifies favorable and unfavorable factors for accessing livelihood development resources by fishermen. For the research methods, secondary data from selected governmental agencies were gathered, and 200 fishermen were interviewed to collect primary data. The results of this research indicate that the income of fishermen is quite good but not stable due to their dependence on marine resources. Moreover, the types of livelihoods in the coastal zone of Nghe An province face certain difficulties with their specific occupational characteristics such as lack of capital, no stable job, reduced marine resources, weather dependence, lack of labor. Based on these, 3 groups of solutions and policies are proposed to promote sustainable livelihood development for coastal fishermen in Nghe An province, such as renewing fishing activities, promoting specialization and associating in maritime manufacturing and processing, as well as developing a variety of occupational groups associated with the exploitation of marine resources.
\end{abstract}

Keywords: livelihoods, fishermen, the coastal zone, Nghe An province, North Central region in Vietnam

\title{
1. Introduction
}

Livelihood is simply defined as a means of securing human life. Among various levels, household is the most popular level of livelihood. In Vietnam, there have been many programs to support communities in order to transform and improve their livelihoods in a sustainable way since 2000. Livelihood activities are greatly influenced by many different factors, including resources (nature, society, human, material, infrastructure, etc.). Researching livelihood status of fishermen in the North Central Coast of Vietnam is an important basis for proposing effective and feasible solutions to develop sustainable livelihoods for coastal fishing communities in the process of integration and development.

Vietnam has 28 provinces and cities directly under the central government with beaches among 63 ones (referred to as provinces and cities with beaches), with 125 coastal districts and 12 island districts, accounting for $42 \%$ of national land area and $45 \%$ of national population (Chambers, R., \& Conway, G. R., 1991). Among these, there are 6 provinces and cities in the North Central region including Thanh Hoa, Nghe An, Ha Tinh, Quang Binh, Quang Tri and Thua Thien Hue. In 2016, its area is 50,778.1 km2 and its population is $10,551.5$ thousand people, accounting for $15.3 \%$ of national area and $11.4 \%$ of national population (NASO, 2017). 
Except for some communities living on narrow coastal plains in districts and towns such as Sam Son Town, Tinh Gia District (Thanh Hoa Province), Hoang Mai Town, Cua Lo Town (Nghe An Province), Ky Anh Town (Ha Tinh Province), Phong Dien, Quang Dien, Huong Tra, Phu Vang Phu Loc (Thua Thien Hue province) ... with livelihoods associated with industry, tourism services, a part of agriculture, and a part of fisheries, remaining communities of the Northern Central region have chosen aquatic livelihoods, including fishing and aquaculture as their main livelihood since ancient times.

However, due to various reasons, livelihoods of these communities are now coping with serious challenges which make their lives more difficult than ever, for example hard and precarious, dangerous working environment, high risk of unemployment, etc. These challenges affect not only people's livelihoods, but also their economic - cultural - social lives of such communities in the North Central region of Vietnam.

The paper is based on a survey of 200 samples of coastal fishing households in Nghe An province which are randomly selected and processed statistically by SPSS 18.0 software. The paper focuses on analyzing and assessing the livelihood status of fishing communities in Nghe An coastal zone, and identifying advantageous and disadvantageous factors which impact on their access to livelihood development resources. On that basis, it proposes solutions of sustainable livelihood development for fishermen in the process of integration and development.

\section{Theoretical Basis}

Livelihoods and sustainable livelihoods

A livelihood comprises the capabilities, assets (including both material and social resources) and activities required for a means of living. A livelihood is sustainable when it can cope with and recover from stresses and shocks and can maintain or enhance its capabilities and assets both now and in the future, while not undermining the natural resource base.

Hence, a livelihood is defined more broadly than an occupation; it comprises all capabilities and assets of a person for their life. Livelihood study is to research on vulnerability contexts, livelihood resources (external and internal), livelihood activities, policies, structure and process, livelihood strategies and livelihood outcomes.

In the world, there have been many important works about community livelihood study. These works initially connect definitions and methods with studies on rural poverty (Nguyen, L. A., Tran, V. P., \& Nguyen, T. L., 2011). Typically, the study of Chambers and Robert (1983) argues that low-income households aim at sustainable livelihoods through combating vulnerability in case of risks and insecurities by means of collateral of tangible assets and intangible assets (Chambers, R., 1983). According to Carney (1998), a livelihood comprises the capabilities, assets (including both material and social resources) and activities required for a means of living (Ashley, C. \& Carney, D., 1999). The Department for International Development (DFID) and International CARE (2010) developed a theoretical framework of livelihoods and sustainable livelihoods. Based on this theoretical framework, many valuable studies have been carried out on livelihoods in rural areas. Policies on identifying sustainable 
community-based livelihoods are determined to be closely related to the macroeconomic context and to external factors. The typical study is of Ellis (1999), which indicates the level of relationship of economic growth, livelihood opportunities and improvement of poverty for people. It also emphasizes roles of institutions, policies as well as social connections and support for livelihood improvement and poverty reduction. The research confirms the sustainability of community livelihoods depends on many factors such as: ability of capital, labor qualifications, community relations and livelihood development policies (Ellis, F., 1999). Each work has its own research approach and gathered research results create a diverse and suggestive picture of community livelihoods in the development process and provide evaluable information as a basis for the study of community livelihoods in current trends of integration and development in Vietnam.

Analysis of sustainable livelihood framework

With regards to livelihoods, we not only describe and analyze socio-economic aspects but also analyze a livelihood framework. Livelihood framework is a tool to be developed for analyzing the factors affecting human livelihood and interaction among them.

The sustainable livelihood framework helps us understand livelihoods of people. The content of sustainable livelihoods has been developed by DFID (The Department for International Development - United Kingdom) through demonstrating the main factors affecting people's livelihoods and specific relationships among those factors (Fig. 1).

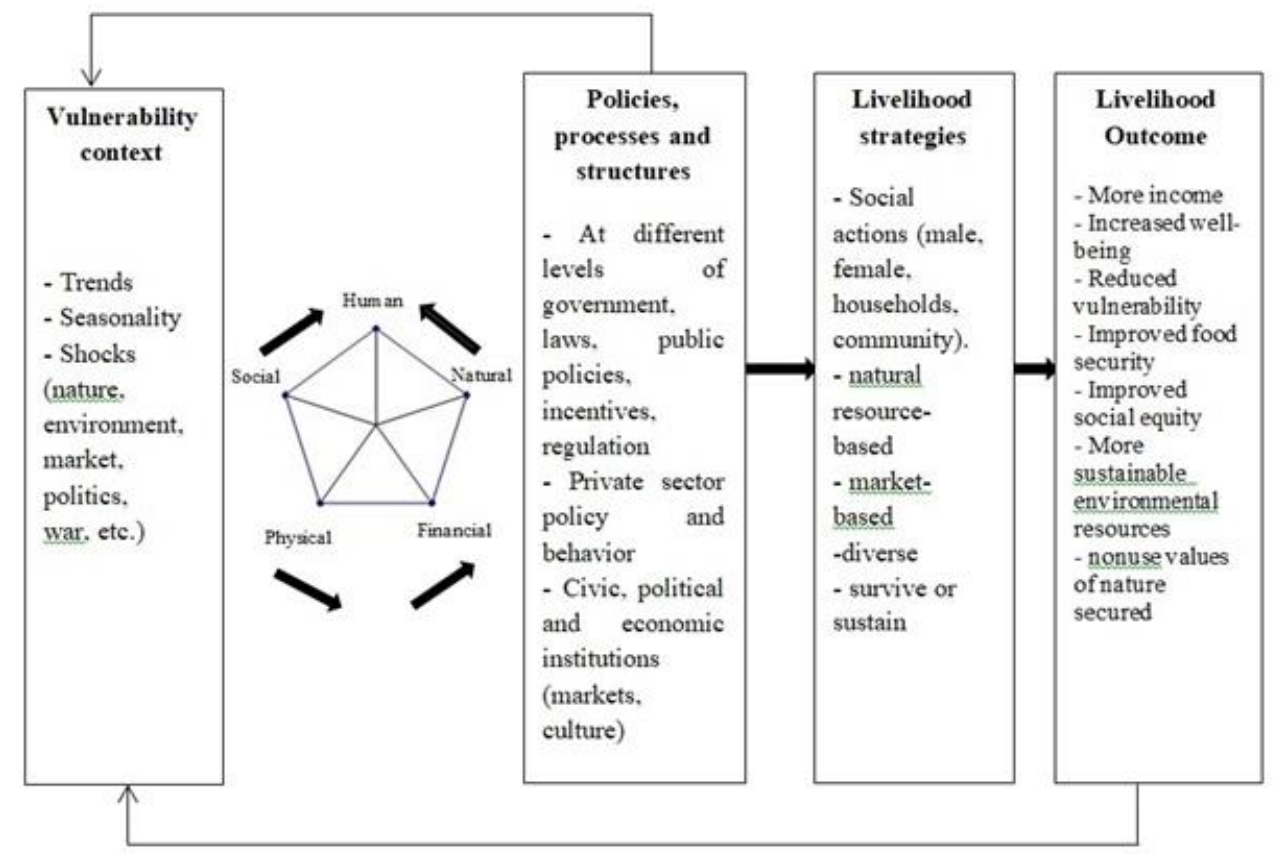

Figure 1. Sustainable livelihood framework

The livelihood framework is important in organizing, researching, identifying and designing support programs for communities. Under this sustainable livelihood framework, human being which is central factor has full of natural, social and environmental resources but may also be vulnerable. In particular, from these resources, each person implements a livelihood 
strategy to reduce vulnerability, improve their income, enhance their quality of life but does not affect natural resources and environment.

The method of sociological investigation and analysis of socio-economic statistics has been applied in accordance with the above-mentioned livelihood framework to assess the current situation and propose solutions to develop livelihoods for fishing community in North central coast of Vietnam through cases in the coastal zone of Nghe An province.

\section{Fishermen}

Fishermen or fishers or fisher folks are people who use nets, fishing rods, traps or other tools to catch and collect fish or other aquatic creatures from rivers, lakes or oceans to make food for them or for other purposes.

Within the scope of this study, we only study and survey livelihoods for marine fishermen and their livelihoods related to marine resources such as: Aqua-culturing, marine product trading, processing and fishing services. Between the ages of 19 and 55, they are capable of working, being employed or unemployed, but want to work and are willing to work.

Correspondingly, the framework for livelihood research and development for coastal fishing communities is shown in Fig. 2.

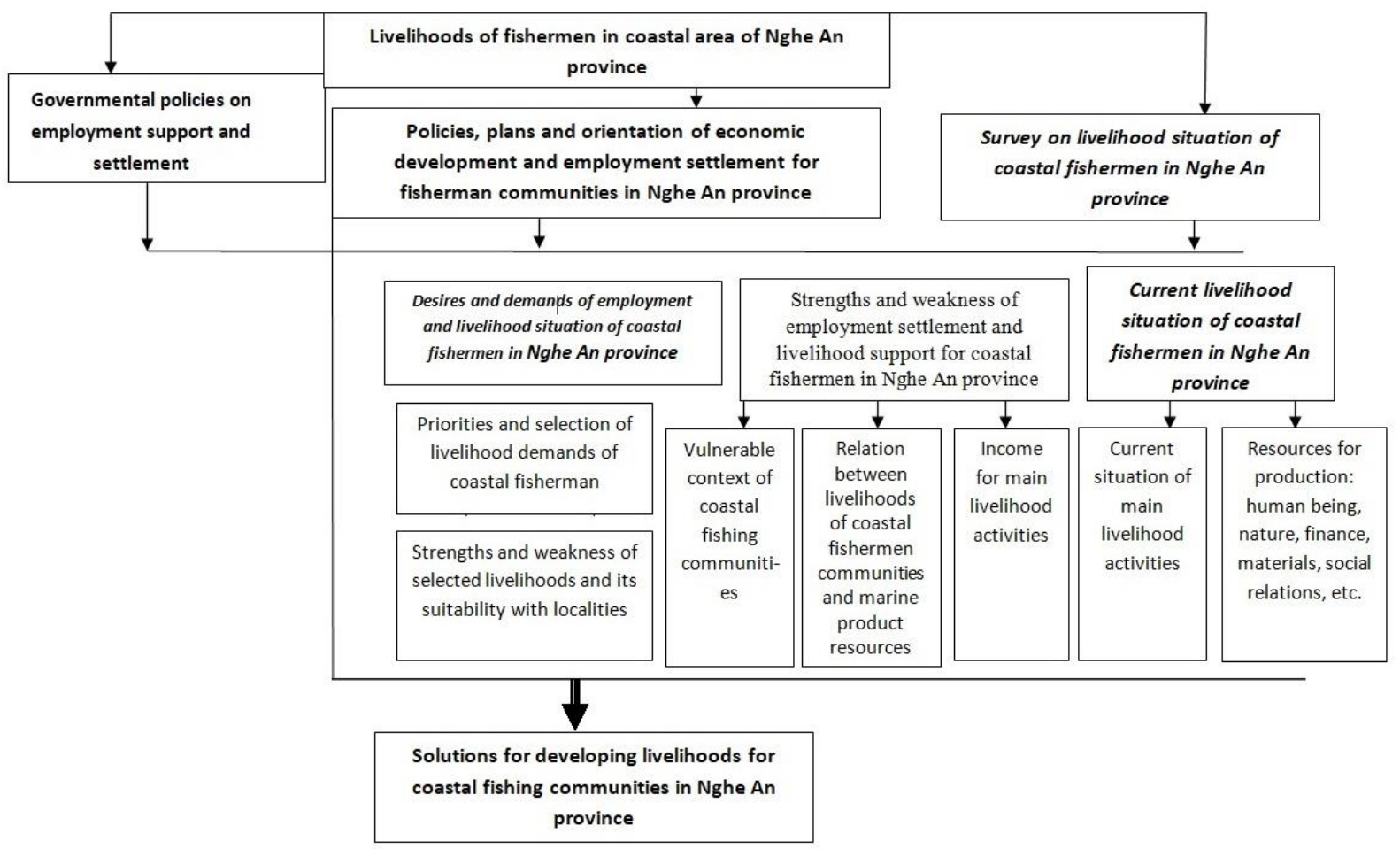

Figure 2. Research model of developing livelihoods for costal fishing comunities in Nghe An province

\section{The coastal zone}

At the National Scientific Conference: "The coastal zone Research and Management" in December 1992, Prof. Joe Baker of the Australian Institute of Marine Science said: A coastal 
zone is defined as a three kilometer inland from the coast, including an extension of a coast to an influential boundary of tidal toward inland.

In studies supporting the environmental sector in Vietnam, International Union for Conservation of Nature and Natural Resources (IUCN) is also concerned about the coastal zones and assumes that "It is difficult to determine what is a coastal zone, but it can be defined as the landward to the influence of tides on rivers, streams and wetlands, or a $10 \mathrm{~km}$ inland, depending on which distance is greater. This understanding is relatively consistent with the research direction of natural conditions and coastal resources (Nguyen, L. A., Tran, V. P., \& Nguyen, T. L., 2011). According to Do Hoai Nam (Nam, H. D., 2003), a coastal zone is the entire coastal land and islands on the territorial waters and the exclusive economic zone of our country. It is the space to arrange seaward socio-economic activities.

Thus, there are many different understandings about the coastal zone; in this study, we focus on surveying and building livelihoods for fishermen in coastal districts and towns with occupational activities relating to marine resources, depending on marine resources.

\section{Material and Method}

\subsection{Method of Secondary Data Collection}

We worked directly with State agencies such as Nghe An Provincial People's Committee, Department of Labor, Invalids and Social Affairs of Nghe An Province, Department of Agriculture and Rural Development in Nghe An Province, Department of Industry and Trade in Nghe An Province, Department of Science and Technology of Nghe An Province, Nghe An Statistical Office, People's Committees of towns and districts: Hoang Mai town, Cua Lo town, Quynh Luu district, Dien Chau district, Nghi Loc district to collect summarized reports from 2010 to 2017, and State data, documents and policies on issues related to livelihoods of coastal fishermen. The collected documents include Statistical yearbook of Nghe An province in 2010 and 2016 (NASO, 2017), Building livelihoods to improve the lives of female labors in the coastal zone of Nghe An province, Report on the summary of labor and employment in the period of 2011 - 2017. Summary report on the results of aquaculture in the period of 2011 - 2015, implementation plan for the period of 2016 - 2020, Scheme on transforming aquaculture from inland to offshore in Nghe An province until 2020.

In addition, secondary data were collected from internal and foreign researchers' publications on books, newspapers, website and other legal documents. Livelihood related publications include: General the coastal zone management (Nguyen, L. A., Tran, V. P., \& Nguyen, T. L., 2011), Sustainable rural livelihoods: practical concepts for the 21 st century (Chambers, R., \& Conway, G. R., 1991), Putting the first, Longman Scientific and Technical (Chambers, R., 1983), Sustainable rural livelihoods (Ashley, C., \& Carney, D., 1999), Rural livelihoods and diversity in developing countries (Ellis, F., 1999). Socio-economic and environmental development of Vietnam's coastal provinces (Nam, H. D., 2003), Vietnam Statistical Yearbook 2017 (GSVN, 2018).

All collected information is clearly cited, analyzed, reviewed, and compared correspondingly with results in the article. 


\subsection{Method of Sociological Investigation}

This is the most important method of the article. We formulated a questionnaire including 43 questions which are multiple choice, one choice, and blank questions (open questions). The content of question refers to characteristics of respondents (gender, age, educational level, and occupational level), type of occupation, assets, income of each household, capital source, advantages and disadvantages, risks and desires of fishing households, etc.

Among 10,551.5 thousand people living in 6 provinces of the North Central region, there are $47 \%$ (4,959 thousand people) of fishermen. We selected to survey 200 fishermen in Nghe An province in 5 districts and towns with sea, including Hoang Mai township (40 questionnaires), Quynh Luu district (40 questionnaires), Dien Chau district (40 questionnaires), Nghi Loc district (40 questionnaires) and Cua Lo township (40 questionnaires). We also selected 200 fishermen in the age between 19 to 55, 100 male and 100 female who are in the main working age group in the family. They have health and intelligence and experience in trades related to marine exploitation and use.

Surveys were conducted in 2017 for 3 times. The 1st time survey was from March 15, 2017 to March 30, 2017, the 2nd time from June 15, 2017 to June 30, 2017, and the 3rd time from October 15, 2017 to October 30, 2017. The surveys were divided into many times because the livelihood activities of fishermen in the North Central Coast region in general, and Nghe An province in particular are seasonal. These activities mainly take place in the summer (from April to July), while in other seasons, they are uneven, and only some sectors such as fishing and exploiting are focused. In particular, from August to October each year, it falls into storm and flood season, so it is highly risky for the research region. Therefore, three-time survey is to accurately assess the level of activity in the livelihood areas in a comprehensive and complete way.

\subsection{Method of Interview With Experts and Managers}

These were oral interviews with experts and managers of Nghe An Department of Agriculture and Rural Development, Department of Labor, Invalids and Social Affairs of Nghe An province, Heads of Division of Agriculture and Rural Development, Division of Labor, Invalids and Social Affairs within the study area. Among 20 questions about livelihood activities of Nghe An coastal fishermen, results of main occupation activities of fishermen are shown partially in Table 3 and the risks in occupational activities shown in Table 1 in the research findings. The total number of experts interviewed was 30 and the total number of managers interviewed was 20. Interview time was from October 15, 2017 to October 30, 2017.

The questionnaires and opinions obtained from interviews were statistically processed with SPSS 18.0 software shown in Table 1 to Table 11 in the research findings. Such tables were adopted to analyze and assess the current situation of livelihoods of coastal fishermen. 


\section{Macrothink}

\section{Research Results and Discussion}

\subsection{The Main Livelihood Resources of Coastal Fishermen in Nghe An Province}

It is defined that the coastal zone of Nghe An province comprises of administrative boundaries of the five districts and towns adjacent to the sea, including Hoang Mai Town, Quynh Luu District, Dien Chau District, Nghi Loc District and Cua Lo Town, with an area of $1,284.62 \mathrm{~km} 2$ on the mainland, 4,230 nautical miles on the sea, and its coastline length of 82 $\mathrm{km}$. Abundant natural conditions, marine resources, and a rich, young, healthy and experienced labor force are great advantages in developing marine-related economic sectors such as seaports, marine transportation, marine tourism and especially marine product aquaculture. However, like many other localities, the coastal zone in Nghe An province is in over-exploitation condition of coastal resources which results to difficulties for communities in terms of livelihood and income because their income depends mainly on fisheries and agriculture.

\section{Human Resources}

The population in Nghe An coastal zone in 2016 is 894,096 people, accounting for $29.18 \%$ of Nghe An's population, with a workforce of 671,600 people, accounting for $75.11 \%$ of the population of whole region and 32.6\% of the force labor in Nghe An province (NASO, 2017).

In general, labors in the coastal zone of Nghe An province are young with the average age of 45 years old. Their education level is low; the number of laborers graduated from secondary school accounts for $65.4 \%$, and the labor force graduated from high school accounts for $32.3 \%$. However, among 200 surveyed labors, nearly half of them were trained in professional skills $(40.8 \%)$. But they are mainly trained at intermediate level, and vocational training level. Their main major is marine product exploitation. Therefore, labor is difficult to access other sources of livelihood regardless of the sea.

In terms of labor resources of households, Nghe An coastal zone has a high average number of people per household: 6 people/household. The average number of employees per household is also 3 people/household. This is an advantage for seafaring works because marine works require a great number of labors. However, the high average number of employees per household is also a difficulty for job creation. Due to the characteristics of seafaring works, it requires healthy male workers rather than female ones, so mostly female workers are at home waiting for their seafaring husbands and son. Therefore, creating jobs for female workers is also a difficult and necessary issue in this the coastal zone. (Table 1) 
Table 1. Some investigated indicators of resources of fishermen

\begin{tabular}{|c|c|c|}
\hline \multicolumn{2}{|l|}{ Indicator } & Ratio (\%) \\
\hline \multicolumn{2}{|c|}{ Average age of surveyed fishermen } & 45 \\
\hline \multirow{3}{*}{ Educational level } & Primary education & 2.3 \\
\hline & Secondary education & 65.4 \\
\hline & High-school education & 32.3 \\
\hline \multirow{6}{*}{ Professional level } & $\begin{array}{l}\text { Intermediate Vocational } \\
\text { school }\end{array}$ & 13.6 \\
\hline & Colleges & 0 \\
\hline & Higher education & 4.5 \\
\hline & Vocational education & 9.1 \\
\hline & Vocational training & 13.6 \\
\hline & No qualification & 59.1 \\
\hline \multirow{3}{*}{ Training major } & Aquaculture (\%) & 8.7 \\
\hline & Economics & 4.3 \\
\hline & Captain $(\%)$ & 4.3 \\
\hline \multicolumn{2}{|c|}{ Average number of people per household } & $6(5.95)$ \\
\hline \multicolumn{2}{|c|}{ Average number of employees per household } & $3(3.19)$ \\
\hline
\end{tabular}

Source: Results of surveys by the research team, 2017

Financial resources (capital)

According to the labor survey results of Nghe An coastal zone, the total average income per household (in 2017) is 3,231 USD/year. The capital for production and business is quite large with an average of 7,162 USD/household. Coastal people have to buy boats to go to the beach, so they need a large amount of capital. In particular, their equity capital only accounts for one third of their remaining loans. Therefore, their investment capacity is not high. (Table 2). 
Table 2. Average capital of fishermen in the coastal zone of Nghe An province, 2017

\begin{tabular}{lll}
\hline Indicator & Amount $(\boldsymbol{U S D})$ & Ratio $(\%)$ \\
\hline Average capital per household & 7,162 & 100 \\
\hline - Loan & 4,854 & 67.78 \\
\hline - Equity capital & 2,272 & 32.22 \\
\hline
\end{tabular}

Source: Results of surveys by the research team, 2017

The system of financial business organizations in the coastal zone of Nghe An is sparse; there is only the Agriculture and Rural Development Bank and the Vietnam Bank for Social Policies, which are State finance organizations. Local credit funds and private organizations have no role in providing capital for labor. Meanwhile most types of careers in the locality have high demand on capital. Especially, transforming from coastal fishing to offshore fishing requires about $86,438 \mathrm{USD} /$ boat while the banks only meet $10 \%$ of that demand.

\section{Natural resources}

With its length of coastline of $82 \mathrm{~km}$ and its exclusive economic zone of about 4,230 square nautical miles, Nghe An's marine resources are evaluated as quite abundant. Total marine reserves are about 78,000 tons, of which fish reserves is about 74,000 tons with the allowable catch of 29,000 - 30,000 tons/year; squid reserves are estimated about 3,000 tons with the allowable catch of 1,500 tons/year; Shrimp reserves is about 700 tons with allowable catch of 350 tons/year. In addition, Nghe An sea also has high-value molluscs such as: Octopus, Clam, scallop, Hakf - crenate Ark, Sergestidae etc. Acetes japonicus are specialties of Nghe An with allowable catch of from 1,500 to 2,000 tons/year (NASO, 2017).

In the coastal zone of Nghe An province, its climate is tropical monsoon, the development of aquatic species with high economic value and export capability is still limited; moreover, with its quite complex terrain condition, the area is very fragmented and has few large areas. This leads to a lot of difficulties in creating large and concentrated commodity production areas, which produce a source of raw materials for limited export processing.

\subsection{Current Situation of Occupations of Fishermen in the Coastal Zone of Nghe An Province}

Nghe An coastal zone has conditions to develop various types of occupations: agriculture, forestry, fishery, industry, services... However, the occupational activities of fishermen whose main livelihoods depend on marine resources are mainly aquaculture and trading, fishery services, welding, making hats, marine product processing and preliminary processing.

Results of survey on fishermen labor in Nghe An coastal zone show that their main occupation is marine product catching. The number of employees participating in this occupation accounts for $20.5 \%$ of a total labor. Workers involved in marine product catching are mainly healthy and experienced males. In 2016, the coastal zone has 1,033 ships and 
boats used for fishing. Most of them are still boats with a capacity of $<90 \mathrm{CV}$, so they still perform mostly nearshore fishing. This has put pressure on coastal fishery resources. (Table 3).

Table 3. Major occupational activities of fishermen in the coastal zone of Nghe An province

\begin{tabular}{|c|c|c|c|c|c|}
\hline No. & Professional activities & $\begin{array}{l}\text { Number of } \\
\text { Labor }\end{array}$ & $\begin{array}{l}\text { Ratio } \\
(\%)\end{array}$ & Gende & \\
\hline \multicolumn{2}{|c|}{ Total number of employees surveyed } & 200 & 100 & Male & Female \\
\hline 1 & Marine product catching & 41 & 20.5 & 41 & 0 \\
\hline 2 & Fish logistic services & 34 & 17.0 & 15 & 19 \\
\hline 3 & Pig farming & 29 & 14.5 & 0 & 29 \\
\hline 4 & Marine product trading & 26 & 13.0 & 11 & 15 \\
\hline 5 & $\begin{array}{l}\text { Marine product processing and } \\
\text { preliminary processing }\end{array}$ & 23 & 11.5 & 11 & 12 \\
\hline 6 & Hat making & 18 & 9.0 & 0 & 18 \\
\hline 7 & Hired workers & 17 & 8.5 & 10 & 7 \\
\hline 8 & $\begin{array}{l}\text { Mechanical engineering (ship and boat } \\
\text { repair) }\end{array}$ & 12 & 6.0 & 12 & 0 \\
\hline
\end{tabular}

Source: Results of the surveys by the research team, 2017

Apart from marine product catching, fishermen in Nghe An coastal zone also have other occupational activities. However, most livelihood activities depend on fishing activities such as: pig farming, marine product trading, fishery logistic services, marine product processing and preliminary processing, because the inputs of these activities are products of fisheries exploitation or outcomes for seafaring works. Particularly, working in cities and towns and making hats are not dependent on fishing but such occupations only accounts for a small percentage in localities.

The above table shows that fishing is a male occupation, accounting for $41 \%$ of male workers. Participants of the remaining occupational activities are mostly female. Pig farming in the coastal zone is only at household level with scale of 10-15 pigs/household due to limited land and use of by-products of marine product processing. This occupation is suitable for women with their seafaring husbands and women involved in marine product processing and preliminary processing. 
Ratio of laborers involved in aquatic products trading in the coastal zone is not high, only accounting for $13 \%$ of laborers and marine products are mainly processed preliminarily before selling. Labor involved in marine product trade includes both men and women, in which men often trade on a larger scale than women.

Processing and preliminary processing of marine products in the coastal zone are on the growing trend. This occupation contributes to improving the value of exploited marine product. In fact, there are only 10-15 marine product processing facilities in the coastal zone, and manual processing activities such as: marine product dissection, sun-drying, toasting account for large ratio. This job is very suitable for women at all ages because it does not require qualifications and skills. Apart from marine product trading in market, female labor can still participate in such activities to increase their income. These occupational activities tend to expand and specialize into groups: Dissections, sun-drying and toasting.

Activities of fishery logistic services including net weaving, mending, ice supply, and boat repair make up a relatively proportion in the structure of occupations in the coastal zone with $17 \%$. Net weaving service is suitable for women with seafaring husbands and son or single female workers. Ice supply is suitable for seasick men who cannot go to sea. If there are favorable conditions for capital and location to expand and modernize these services, their income will be further improved. Ship and boat repair services can be operated all year-round, because upon each voyage, ships and boats need repairing and upgrading again. However, this occupation requires male and skillful workers.

Women in the coastal zone of Nghe An province, in addition to pig farming, trading and preliminary processing of marine product, have a secondary occupation of making hats. Its income is not high with an average of 17,29 USD/employee/month and it depends on women's skills and experience as well. But it is considered as an occupation that contributes to solving the seasonality of the marine occupation and increasing income for fishermen. Actual situation at communes and districts in the coastal zone shows that, if bamboo and rattan weaving is implemented in the locality, it is possible to create income for women from $51,86 \mathrm{USD}-64,83 \mathrm{USD} / \mathrm{month}$. Therefore, it is possible to replace the hat-making with bamboo and rattan weaving to improve income for female workers.

\subsection{Current Situation of Income of Fishermen Households}

Fishing brings about the highest income among all types of occupations for surveyed fishermen in the Nghe An coastal zone because it is a traditional occupation. Moreover, it provides inputs and materials for other industries such as marine product trading, marine product processing and preliminary processing. Its average income is about 1,988 USD/year. Marine product trade and fishery logistics also create good income. Ship and boat repairing service requires technical skills, so it has not been developed in the coastal zone. Other occupations contribute only a small part to household income with the average income below 1,000 USD/year. (Table 4) 
Table 4. Average income of fishermen surveyed in the coastal zone of Nghe An province

\section{No. Income source in 2017}

Amount (USD/year)

I Income from different types of occupations

$1 \quad$ Marine product catching $\quad 1,988$

$2 \quad$ Marine product trading $\quad 1,556$

$3 \quad$ Fish logistic services $\quad 1,072$

$4 \quad$ Hired workers in cities $\quad 1,055$

$5 \quad$ Pig farming $\quad 881$

$6 \quad$ Marine product processing and preliminary processing

$7 \quad$ Hat making $\quad 640$

$8 \quad$ Mechanical engineering (ship 186 and boat repair)

II Total income of fishermen households

$$
\begin{array}{ll}
\text { + Average income/household } & 3,231 \\
\text { + Average income/labor } & 1.365 \\
\text { + Average income/person } & 899
\end{array}
$$

Source: Results of labor survey in the coastal zone, 2017

The average income/household in 2017 of surveyed fishermen in the coastal zone of Nghe An province is 3,231 USD/household. However, their income is not stable due to fishing dependence. In fact, nearshore fishing in the locality is under pressure due to reduced coastal resources.

\subsection{Difficulties in Livelihood Activities of Fishermen}

Difficulties in livelihood and occupation activities of fishermen in the coastal zone of Nghe An province are very diverse but mainly are lack of capital. The majority of workers involving in marine product trading, processing, catching, pig farming need capital to expand their scale and buy high-capacity boats for offshore fishing. $13 \%$ of surveyed workers said 


\section{Macrothink}

that they had no problem. They are workers who have their own boats for offshore fishing, single or unmarried female workers, and those with good economic conditions. (Fig. 3a)

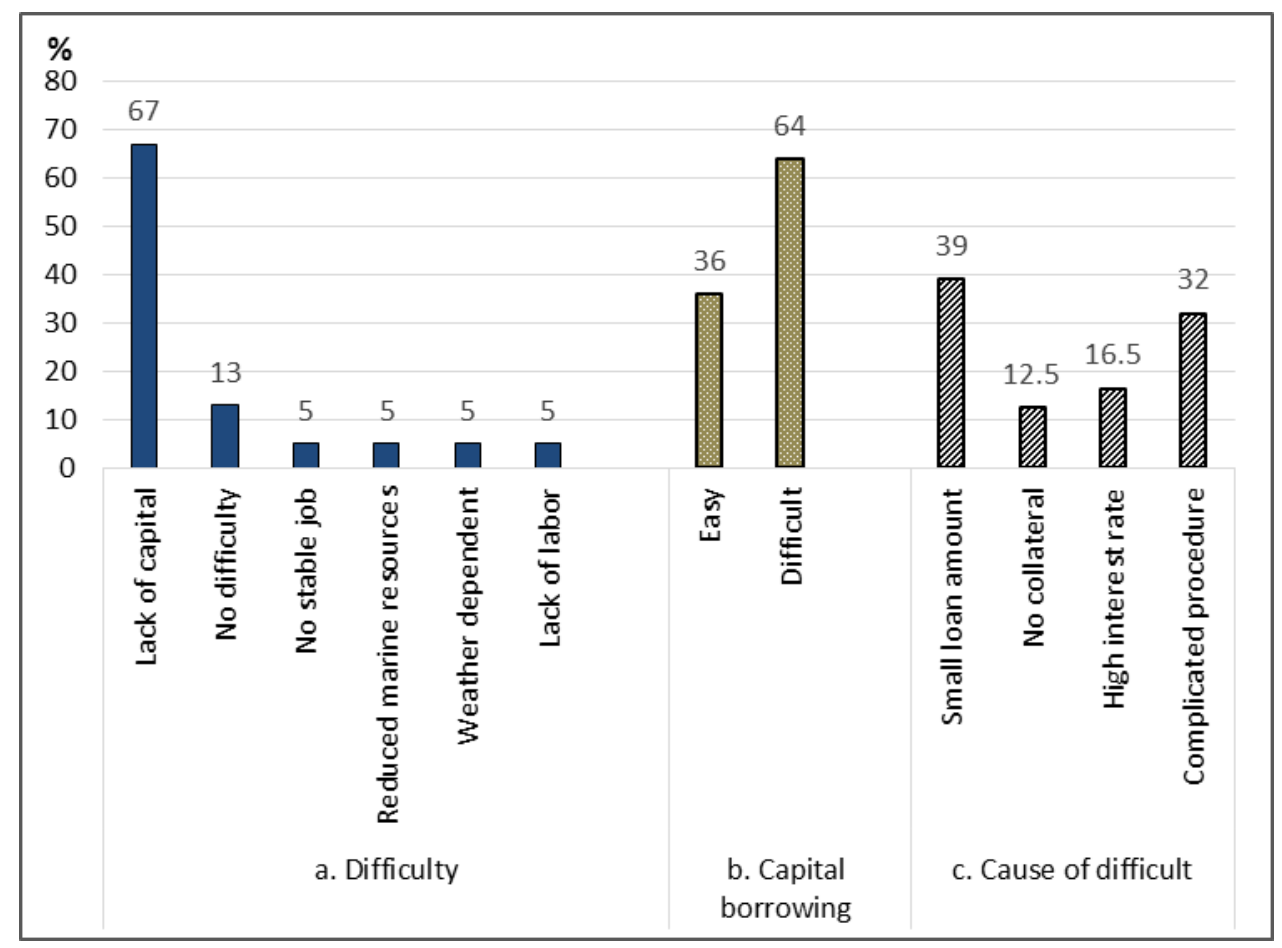

Figure 3. Main difficulties, difficulties levels and several causes of fishermen surveyed in the coastal zone of Nghe An province

Source: Labor survey data in the coastal zone of Nghe An province, 2017

It is quite easy for fishermen to access to capital fund but the loan amount is small, the loan term is short, and interest rates are not preferential. In particular, for poor fishermen and disadvantaged households, it is easy to borrow loans through Vietnam banks for social policies but the loan amount is very low. The State has not had any separate loan policy for marine trades yet (Fig. 3b). It is the most important reason causing difficulties for people in accessing capital, accounting for 39\%, following by complicated procedures with $32 \%$. Moreover, lack of collateral and high bank interest rates are also difficulties that people have to accept, with $12.5 \%$ and $16.5 \%$ respectively. Causes of difficulties in borrowings are shown in Fig. 3c.

\subsection{Risks of Fishermen in the Coastal Zone of Nghe An Province}

\section{Income risk}

In comparison between fishermen households' income in 2017 with that in 2016, majority of labors $(46 \%)$ said that their income increased thanks to occupation transformation. In addition, a relative part of labors (37\%) said that their income decreased. (Fig. 4a). 


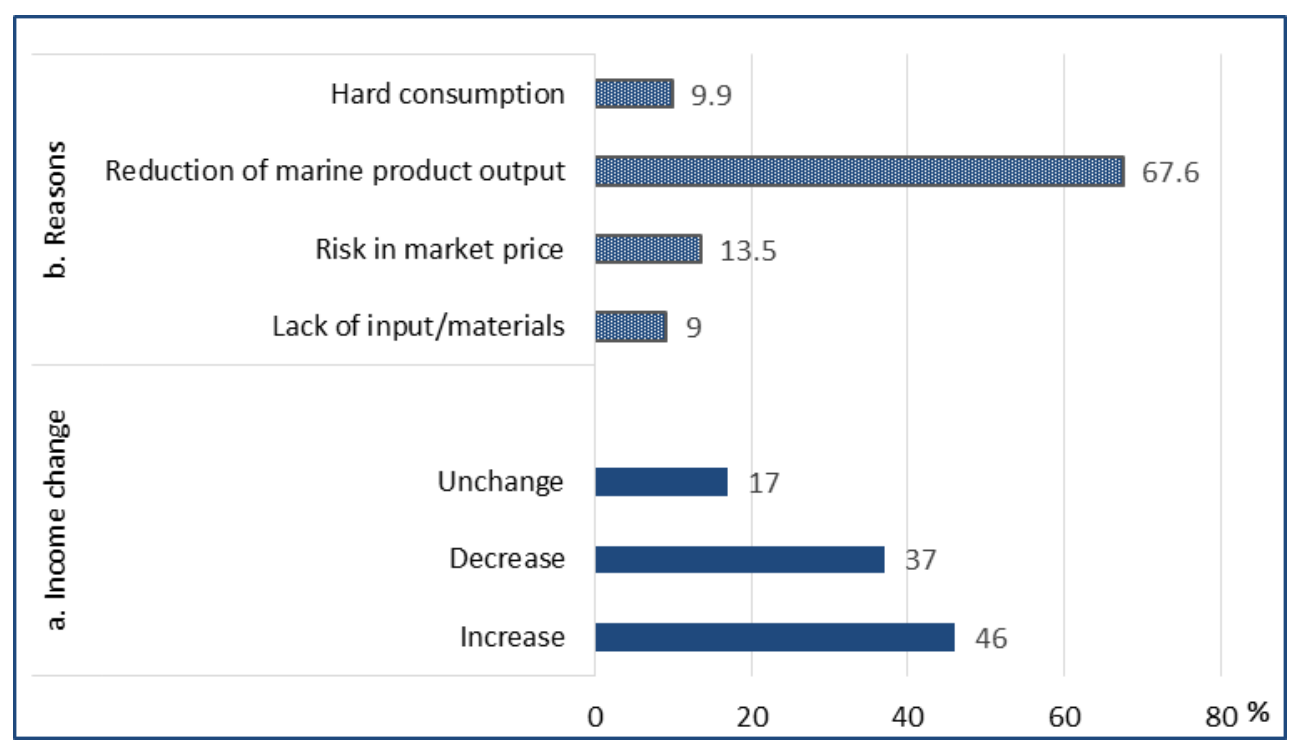

Figure 4. Evaluating on income change and causes of decrease in fishermen households' incomes in the coastal zone of Nghe An province

Source: Labor survey data in the coastal zone of Nghe An province, 2017

The income decrease demonstrates that the livelihood activities of fishermen households bear risks. The main risk is a reduced catching productivity of marine products $(67.6 \%$ of respondents). This proves that fishing activities have an important meaning in their family's income. Marian product output has decreased due to marine product resources, especially near-shore resources tend to reduce. (Fig. 4b)

Due to decrease in marine resources, other related types of occupations also tend to reduce income and workers in such occupations tend to be underemployed.

Marine product exploitation and preliminary processing activities are directly affected by weather. Unfavorable weather such as rain, storms and floods causes risks for fishing such as reduced reserves, loss of life and property, even no ability of sailing for boats. Currently, in the coastal zone of Nghe An province, the preliminary processing activities, including dissecting, sun-drying and boiling are manual. Therefore, if the weather is rainy and windy, it will not be favorable for fish drying.

In addition to fishing, in the coastal zone of Nghe An province, there are other livelihood activities such as: Marine product preliminarily processing, trading, net weaving and boat welding, etc., which depend on exploitation activities. However, each voyage usually takes 2-3 days for inshore fishing and more than 7 days for offshore fishing. Such peculiarity of exploitation leads to the irregular nature of other occupations in the locality. Low productivity, catches, weather risks and natural disasters result in decreased income and high-rate unemployment of a range of other dependent livelihood activities.

The market is also one of the risk factors of livelihood activities. Input price: gas and oil for voyage, price of output (selling price of fish) is squeezed or owed by traders. (Table 5). 
Table 5. Types of risks of fishing communities in Nghe An coastal zone in professional activities

\begin{tabular}{|c|c|c|c|c|c|c|}
\hline \multirow{2}{*}{$\begin{array}{l}\text { Type } \\
\text { occupation }\end{array}$} & \multicolumn{6}{|c|}{ Type of risk } \\
\hline & Tendency & Seasonality & Weather & Market & Diseases & Health \\
\hline Marine catching & & $\mathrm{x}$ & $\mathrm{x}$ & $\mathrm{x}$ & $X$ & $X$ \\
\hline $\begin{array}{l}\text { Marine product } \\
\text { trading }\end{array}$ & $\mathrm{x}$ & $\mathrm{x}$ & $\mathrm{x}$ & $\mathrm{x}$ & & \\
\hline $\begin{array}{l}\text { Fish logistic } \\
\text { services }\end{array}$ & $\mathrm{x}$ & $\mathrm{X}$ & $\mathrm{x}$ & $\mathrm{x}$ & $\mathrm{x}$ & \\
\hline $\begin{array}{l}\text { Hired workers } \\
\text { in cities }\end{array}$ & $\mathrm{x}$ & $\mathrm{x}$ & $\mathrm{x}$ & $\mathrm{x}$ & & $X$ \\
\hline Pig farming & & $\mathrm{x}$ & & $\mathrm{x}$ & $\mathrm{x}$ & \\
\hline $\begin{array}{l}\text { Marine product } \\
\text { processing and } \\
\text { preliminary } \\
\text { processing }\end{array}$ & & $\mathrm{x}$ & $\mathrm{x}$ & $\mathrm{x}$ & $\mathrm{x}$ & \\
\hline Hat making & & & & $\mathrm{x}$ & & \\
\hline $\begin{array}{l}\text { Mechanical } \\
\text { engineering } \\
\text { (ship and boat } \\
\text { repair) }\end{array}$ & $\mathrm{x}$ & $\mathrm{x}$ & & $\mathrm{x}$ & & \\
\hline
\end{tabular}

Source: Labor survey data in the coastal zone of Nghe An province, 2017

Discussions with local people showed that most of the occupational activities in the coastal zone of Nghe An are affected by most types of risks. In particular, it is considered that fishing - the main livelihood in the locality is subject to $5 / 6$ risk except for risk of disease. The risk of livelihood activity makes other dependent livelihood activities such as: Marine product preliminary processing, trading and fishery services are also subject to many risks. Only hat making is hardly at risk. However, it has just emerged and is considered only a secondary occupation to contribute to the increase in family income. 
4.6. Recommendations for Sustainable Livelihood Development Solutions and Policies for Coastal Fishermen in Nghe An Province

3 groups of proposed solutions and policies to promote sustainable livelihoods development for coastal fishermen in Nghe An province, including renovating fishing activities; promoting specialization and linkage in marine product manufacturing and processing; and developing a variety of occupational groups associated with the exploitation of marine resources.

\begin{tabular}{|c|c|c|}
\hline & Solutions and policies & Details \\
\hline 1 & Renovating fishing activities & $\begin{array}{l}\text { - Gathering fishing households into a fishing inter-family groups } \\
\text { to share about fishing, processing and trading; } \\
\text { - Continuing to promote transformation from inshore fishing to } \\
\text { offshore fishing; } \\
\text { - Building community-based marine resource management } \\
\text { models in the coastal zone; } \\
\text { - Training for captains, crews and seafaring techniques for } \\
\text { fishermen; } \\
\text { - Planning fishing areas and developing fishing plans for each } \\
\text { region. }\end{array}$ \\
\hline 2 & $\begin{array}{l}\text { Promoting specialization and linkage in } \\
\text { marine product manufacturing and } \\
\text { processing }\end{array}$ & $\begin{array}{l}\text { - Coordinating between processing facilities and factories with } \\
\text { marine product purchasing and trading groups and aquaculture } \\
\text { localities to ensure a regular source of raw materials for } \\
\text { processing in unfavorable weather conditions for natural catch; } \\
\text { - Planning and constructing fish sauce processing villages or } \\
\text { establishing fish sauce processing cooperatives in association } \\
\text { with each other in production and consumption to combat price } \\
\text { squeezing; } \\
\text { - Building a marine product processing factory (canned, dried } \\
\text { and frozen products) for clusters of coastal communes. }\end{array}$ \\
\hline 3 & $\begin{array}{l}\text { Developing a variety of occupational } \\
\text { groups }\end{array}$ & $\begin{array}{l}\text { - Developing fishery logistic services: establishing fishery } \\
\text { logistic facilities in charge of supplying petroleum, oil, ice, } \\
\text { fishing tools, boat repair services for local fishermen and } \\
\text { external fishermen as well. } \\
\text { - Developing aquaculture activities: planning fish cage farming } \\
\text { sites on the sea and handing over to households or contracting to } \\
\text { economic organizations for farming. } \\
\text { - Promoting commercial and tourism services: forming an } \\
\text { eco-tourism area in combination with resort, medical treatment } \\
\text { and tourism conferences and seminars to overcome the } \\
\text { seasonality of sea tourism. } \\
\text { - Developing secondary occupational groups: pig farming for } \\
\text { meat combined with wine making in household scale. }\end{array}$ \\
\hline
\end{tabular}

\section{Conclusion}

The coastal zone of Nghe An province basically has had suitable natural, economic and social resources conditions for economic development and job creation. However, some important resources have been in the process of construction and completion, so they do not meet the demand for various types of occupations.

The types of occupations of the Nghe An coastal zone are quite diverse but depend mainly on the sea. Most male laborers participate in fishing activities, while women do related jobs such as pig farming, marine product trading, processing and preliminary processing. In general, income of fishermen is quite good but not stable due to their dependence on marine resources. 
In addition to the favorable conditions, the types of livelihoods in the coastal zone of Nghe An province face certain difficulties with their specific occupational characteristics. For improvement of fishermen life and sustainable development of marine resources, we proposes different types of occupations, orientations and methods to develop the following types of occupations: fishing; marine product trading; fisheries logistics services; fish sauce processing, marine product processing and preliminary processing; aquaculture; tourism; wine-making in combination with pig farming; bamboo and rattan weaving; transforming occupation for workers in industrial zones; other activities such as: transport services, labor export, hired labor.

\section{References}

Akyol, O., Ceyhan, T., \& Ünal, V. (2006). Fishery co-operatives and societies of Marmara Region and their roles in bluefish fishery. Aegean University Journal of Fisheries \& Aquatic Sciences, (3-4), 379-383, ISSN 1300-1590.

Anonymous. (1999). Indicators for sustainable development of marine capture fisheries. FAO technical guidelines for responsible fisheries. Rome, Italy, FAO Press., 68 pp.

Anonymous. (2013). Situation analysis report (in Turkish). Retrieved from http://www.trakyaka.org.tr/uploads/docs/862016kqfRQq.pdf

Ashley, C., \& Carney, D. (1999). Sustainable Livelihoods: Lessons from Early Experience. Nottingham, England, Russell Press., 64.

Çeliker, A., Korkmaz, Ş., Demir, A., Gül, U., Dönmez, D., Demir, A., \& Kalanlar, Ş. (2006). Socio-economic analysis of the Black Sea Region fisheries (in Turkish) (Report No: 143). Ankara, Turkey, AERI Press, 122 pp.

Ceyhan, V., \& Gene, H. (2014). Productive efficiency of commercial fishing: evidence from the Samsun province of Black Sea, Turkey. Turkish Journal of Fisheries and Aquatic Sciences, 14, 309-320. https://doi.org/10.4194/1303-2712-v14_2_02

Chambers, R. (1983). Rural Development: Putting the Last First. Longman Scientific \& Technical, Essex, UK, Longman House., 246 pp.

Chambers, R., \& Conway, G. R. (1991). Sustainable Rural Livelihoods: Practical Concepts for the 21 st Century. Retrieved from

https://www.ids.ac.uk/publications/sustainable-rural-livelihoods-practical-concepts-for-the-21 st-century/

Colloca, F., Cirespi, V., Cerasi, S., \& Coppola, S. R. (2003). Evolution of the artisanal fishery in Cilento, Italy: Case Study. FAO, COPEMED, 60 pp.

Cuong, M. N. (2013). Some Basis Issues of Social Policies in Vietnam Today. Hanoi, Viet Nam, NPP Press, 351 pp.

Dartay, M., Duman, E., Duman, M., \& Ateşşahin, T. (2009). The socio-economic analysis of fishermen Pertek region in Keban Dam Lake. E.U. Journal of Fisheries \& Aquatic Sciences, 
26(2), 135-138, ISSN: 1300-1590.

Dinh, V. N. (2008). Textbook of Social Security. Hanoi, Viet Nam, NEU Press., 281 pp.

Doğan, K., \& Gönülal, O. (2011). Gökçeada (Aegean Sea) fishery and socioeconomic structure of fishermen. The Black Sea Journal of Science, 2(5), 57-69, ISSN: 1309-4726.

Ellis, F. (1999). Rural livelihoods and diversity in developing countries. Retrieved from http://www.odi.org.uk/nrp/40.html

FAO (1999). Indicators for sustainable development of marine capture fisheries. Retrieved from http://www.fao.org/3/a-x3307e.pdf

Griet, S., \& Paul, V. L. (2017). Rural livelihood transformations and local development in Cameroon, Ghana and Tanzania. Working Paper. International Institute for Environment and Development. https://pubs.iied.org/10811IIED/?k=urban

GSVN. (2018). Statistic Yearbook of Vietnam 2017. Hanoi, Viet Nam, Statistical Press, 997 pp.

Güngör, H., Güngör, G., Zengin, M., \& Demirkol, C. (2012). Social profiles of Marmara Sea fisheries and dynamics affecting fishery. Proceedings of Marmara Sea Fisheries: Resource Management, Sectoral Issues and Strategies for the Future (pp 113-122). Silivri, İstanbul.

Hoi, C. N. (2019). Sea and island sustainable management in Vietnam. Hanoi, Viet Nam, NPP Press, $450 \mathrm{pp}$.

Jackson, E. (2014). Effects of climate change on inland aquatic systems, fisheries and livelihoods of riparian communities in Africa. Department of Biological Sciences, CONAS,

Kurtar, K. G. (2008). A look at the state aid in our country in the context of global developments in fisheries policy (EU Expertise Thesis) (in Turkish). Ministry of Agriculture, Ankara, Turkey.

Lery, M., Prado, J., \& Tietze, U. (1999). Economic viability of marine capture fisheries. Rome, Italy, FAO Press., 130 pp.

Loi, N. T., \& Hoa, Q. N. (2017). Economics development model of Vietnam - Current situation and orientation toward 2030. Hanoi, Viet Nam, NPP Press., 233 pp.

Luke, A., \& George, A. (2017). Sustainable Rural Livelihoods: Elusive Post-Colonia Development Project in Nigeria? (pp. 28-42). International Journal of Political Science, 3(4). https://doi.org/10.20431/2454-9452.0304003

Makerere University. Climate Change and rural livelihoods Round Table, 4th Sept. 2014. Retrieved from

https://ug.ambafrance.org/IMG/pdf/4.presentation_m.efitre_on_effects_of_climate_change_o n_insland_aquaticsystems_fisheries_and_livelihoods_of_riparian_communities_in_africa.pdf ?2224/75580ee20c0633cf4cb67dace84c09c4d36d6162

MRC. (2006). Livelihood approaches and fisheries management in the Lower Mekong Basin. 
http://www.mrcmekong.org/assets/Publications/report-management-develop/TAB-Man-RecNo5-livelyhood-approaches.pdf

Nam, H. D. (2003). Eco-social and environmental development in coastal provinces of Vietnam. Hanoi, Viet Nam. SSP Press, 405 pp.

NAPPC. (2016). Project on transforming fishery exploiting from demersal zone to offshore zone in Nghe An toward 2020. Retrieved from

https://thuvienphapluat.vn/van-ban/Thuong-mai/Quyet-dinh-5896-QD-UBND-De-an-Phat-tri en-doi-tau-khai-thac-hai-san-Nghe-An-2016-2020-333471.aspx

NASO. (2017). Statistical yearbook of Nghe An province in 2016. Hanoi, Viet Nam, Statistical Press, 412 pp.

Nguyen, L. A., Tran, V. P., \& Nguyen, T. L. (2011). General Coastal Zone Management. Nha Trang, Vietnam, NTU Press, 256 pp.

Phuong, M. H. (2019). Eco-tourism development for major economic zone in the North Central Region of Vietnam in the context of international integration. Hanoi, Viet Nam. NPP Press., 453 pp.

Quy, T. T. (2018). Enhancing the implementation of social security policies to assure the socail advances and equality in Vietnam today. Communist Review, 904(2), 87-93. http://www.tapchicongsan.org.vn/Home/Nghiencuu-Traodoi/2018/49969/Day-manh-viec-thu c-hien-chinh-sach-an-sinh-xa-hoi-bao.aspx

Steel, G., \& Van, L. P. (2017). Rural livelihood transformations and local development in Cameroon, Ghana and Tanzania. IIED, London. http://pubs.iied.org/10811IIED, 39 pp.

\section{Copyright Disclaimer}

Copyright for this article is retained by the author(s), with first publication rights granted to the journal.

This is an open-access article distributed under the terms and conditions of the Creative Commons Attribution license (http://creativecommons.org/licenses/by/4.0/). 